DOI https://doi.org/10.30525/978-9934-26-182-4-13

\title{
СУЧАСНІ КОНЦЕПЦІї ІНДУКУВАННЯ ПОЛОГОВОЇ ДІЯЛЬНОСТІ
}

\author{
Наритник T. Т. \\ кандидат медичних наук, \\ дочент кафедри акушерства та гінекології № 1 \\ Національний медичний університет імені О. О. Богомольия \\ м. Київ, Украӥна
}

Індукція пологів - це ініціювання пологової діяльності у вагітних за відсутності спонтанного початку. Існують різні погляди щодо термінів розродження, показань та протипоказань до індукції, методів індукції, а також можливих ускладнень. Для обгрунтованого визначення показань до індукції надзвичайно важливим $\epsilon$ встановлення точного терміну вагітності.

Дискутабельними залишаються питання щодо показань до індукції пологів. Згідно з уніфікованими протоколами показаннями до індукції пологів $\epsilon$ : термін вагітності 41 тиждень і більше, передчасний розрив плодових оболонок, гіпертензивні порушення, обтяжений стан матері, що вимагає розродження, внутрішньоутробна загибель плода, затримка внутрішньоутробного розвитку плода та інші ускладнення вагітності, які $\epsilon$ показанням до розродження. Показаннями до індукції пологів $є$ термін вагітності більше 41 тижня, включаючи жінок 3 рубцем на матці після попереднього кесаревого розтину, передчасний розрив плодових оболонок, антенатальна загибель плода, бажання вагітної, зміна маси та розмірів плода [4]. Можливість індукції пологів у жінок з рубцем на матці та у жінок з надмірною вагою розглядати в індивідуальному порядку [5]. В Україні бажання жінки не $\epsilon$ показанням до індукції. Індукція проводиться лише за наявності поінформованої згоди. У той же час вагітна може відмовитися від індукції пологів.

Міжнародні рекомендації пропонують безліч методів індукцій, що відрізняються між собою ефективністю, вартістю, умовами застосування, наявністю показань та протипоказань. У той самий час керівництва різних країн віддають перевагу різним медикаментозним чи механічним методам індукції. Відповідно до уніфікованих акушерських протоколів методи індукції: медикаментозні - простагландини Е1 та Е2, немедикаментозні ламінарії. Методом вибору індукції пологів при зрілій шийці матки $\epsilon$ 
амніотомія 3 наступним внутрішньовенним введенням розчину окситоцину [1, 2, 3].

Всесвітня організація охорони здоров'я (ВООЗ) рекомендує використовувати для індукції пологів при незрілій шийці простагландини E1 або Е2, при цьому перевага надається простагландинам Е1 (мізопростолу) пероральному або вагінальному його застосуванню [6]. ВОО3 наголошує, що мізопростол відрізняється низькою вартістю, високою ефективністю, відсутністю спеціальних умов зберігання. При недоступності простагландинів або при наявності протипоказань до їх застосування рекомендується балонний катетер у поєднанні 3 окситоцином. Балонний катетер і простагландини характеризуються схожою ефективністю, проте балонному катетеру слід надавати перевагу при індукції пологів у жінок з рубцем на матці, так як цей метод характеризується нижчою ймовірністю гіперстимуляції матки. Згідно 3 рекомендаціями 2018 року - найкращим методом індукції пологів $\epsilon$ вагінальний простагландин Е2, який можна використовувати у вигляді гелю, таблеток або песарію з контрольованим вивільненням. Простагландин Е1 рекомендовано лише у випадках антенатальної загибелі плода. У той же час, пропонується застосовувати для індукції пологів не тільки простагландини Е2, а також простагландини Е1. Серед механічних методів використовується балонний катетер Фолея та ламінарії. Хірургічні методи - амніотомія окремо або з окситоцином не повинні при цьому бути як основний метод індукції пологів, якщо не існує конкретних клінічних причин для невикористання простагландинів.

Рекомендовані механічні методи індукції, а саме балонний (цервікальний) катетер (Фолея, Кука). За наявності протипоказань слід використовувати простагландини Е2 вагінально або ендоцервікально (гелі простін та цервіцил відповідно). При зрілій шийці матки: штучний розрив плодових оболонок із подальшим дозованим введенням розчину окситоцину. При неефективності використання балонного катетера можливе введення динопростонового гелю (до 3 доз), а в разі потреби повторне встановлення балонного катетера.

Балонний катетер є одним із найдавніших методів індукції пологів, який знову набирає популярність завдяки зручності установки, доступній ціні, високій ефективності та низці переваг у порівнянні 3 медикаментозними методами індукції, а саме: метод вибору у жінок з рубцем на матці, може бути використаний після введення простагландинів Е2, якщо ефект був мінімальний, або відсутність ефекту, а також за відсутності умов амніотомії. Балонні катетери (Фолея, Кука) використовуються для дозрівання шийки матки шляхом тиску на внутрішню вісь шийки матки, 
розтягуючи нижній сегмент матки та підвищуючи секрецію місцевих простагландинів.

Процедура установки балонного катетера: виконується при випорожненому сечовому міхурі, шийка матки попередньо обробляється антисептиком. Можливі різні способи введення катетера: пальцеве або 3 використанням дзеркал та інструментарію. У балон вводиться 30-80 мл стерильної води або 0,9\% розчину хлориду натрію. Встановлюється балонний катетер на 12-18-годинний проміжок часу. 3 появою дискомфорту можливе зменшення обсягу введеної рідини або видалення катетера. При розвитку регулярної пологової діяльності - катетер експульпується самостійно.

У багатьох клінічних дослідженнях було доведено, що простагландин E1 безпечний та ефективний для стимуляції дозрівання шийки матки та індукції пологів. Мізопростол має багато переваг перед іншими препаратами простагландинів, а саме термостабільність та низьку вартість. Найчастіше при доношеній вагітності рекомендується застосовувати 25 мкг мізопростолу кожні 6 годин, вводячи в задне склепіння піхви, або 25 мкг кожні 2 години перорально. Якщо після індукції за допомогою міізопростолу необхідно подальше введення окситоцину, його слід починати не раніше ніж через 4 години після введення останньої дози мізопростолу. На сьогоднішній день розробляється лікарська форма мізопростолу для вагінального застосування, що складається 3 полімерного чіпа з контрольованим звільненням для поступової доставки 200 мкг мізопростолу в піхву.

Підсумовуючи міжнародні, а також вітчизняні рекомендації та протоколи, серед нерекомендованих методів індукції пологів виділяють фармакологічні: пероральні, внутрішньовенні та екстраамніотичні простагландини Е2, гіалуронідазу, кортикостероїди, естрогени, релаксин, антигестагени, гомеопатію, рицинова олія, гарячі ванни, клізми, статевий акт.

Можливі ускладнення при індукції пологів: тахісістолія або гіпертонус (без аномалій частоти серцевих скорочень плода) або гіперстимуляція матки (з порушеннями частоти серцевих скорочень плода) після використання простагладнінів; випадання пуповини (після амніотомії); розрив матки, післяпологова кровотеча (індукція пологів окситоцином пов’язана з підвищеним ризиком ранньої післяпологової кровотечі).

Таким чином, проаналізуючи досвід застосування сучасних методів індукції пологів, можна знизити кількість необгрунтованих індукцій. Вибір методу індукції та пріоритетність використовуваних препаратів залежить від показань та протипоказань у кожному конкретному випадку. 
Індивідуалізація підходів до методів індукції дозволить збільшити кількість вдалих прогнозів пологів та знизити частоту можливих ускладнень.

\title{
Література:
}

1. National Core Maternity Indicators Web report | Last updated: 18 Nov 2021 | Topic: Mothers \& babies | Citation AIHW Australian Institute of Health and Welfare (2021) National Core Maternity Indicators, AIHW, Australian Government, accessed 18 November 2021.

2. Queensland Health, Statistical Services Branch. Perinatal statistics Queensland. 2015.

3. Queensland Clinical Guidelines. Vaginal birth after caesarean section (VBAC). Guideline No. MN15.12-V4-R19. [Internet]. Queensland Health. 2015. [cited 2016 August 15]. Available from: http://www.health.qld.gov.au

4. Inducing labour. Clinical guideline Published: July 2018

Available from: http://www.nice.org.uk/guidance/cg70

5. Inducing labour NICE guideline Published: 4 November 2021 http://www.nice.org.uk/guidance/ng207

6. WHO recommendations: induction of labour at or beyond term World Health Organization 2018.

DOI https://doi.org/10.30525/978-9934-26-182-4-14

\section{МОНІТОРИНГ ВУГЛЕВОДНОГО І ЛІПІДНОГО ОБМІНУ У ХВОРИХ НА ЦУКРОВИЙ ДІАБЕТ 2 ТИПУ НА ТЛІ ГІПОТИРЕОЗУ $З$ УРАХУВАННЯМ СТАНУ МІКРОБІОЦЕНОЗУ КИШЕЧНИКА}

\author{
Остапенко К. I. \\ здобувач вищої освіти 2 курсу групи 1
}

спеціальності 224 - Технології медичної діагностики та лікування освітньої програми: «Лабораторна діагностика»

Національний фармачевтичний університет м. Харків, Украӥна

На сьогодні, актуальність проблеми пов язаної з цукровим діабетом обумовлена маштабністю розповсюдження. Діабет входить у трійку захворювань, які часто приводять до інвалідності та смертності [1]. 